\title{
Michigan's Experiences with the Federal Education Block Grant
}

\author{
C. Phillip Kitarney \\ School of Education. The University of Michigan. Ann Arbor. Ml $48114 \%$. U.S.A
}

\begin{abstract}
The results of a detailed study undertaten in Michigan wo determine the impact of the Chapter 2 block grant in its first two vears of implementation. 1982-1983 and 1983-1984. are summarized in this article. Following a discussion of changes in intergovernmental relationships that resulted from Chapter 2, major state decisions and actions that centered on the hloch grant program are described. General and specific impressions of the impact of Chapter 2, based on an in-depth study of nine public school districts and four non-public schools, comprise the major portion of the article.
\end{abstract}

\section{INTRODUCTION}

DESPITE its traditional junior role in public school finance, the federal government during the 1960) and 1970s became a significant force in American education. At the elementary and secondary levels. federal expenditures rose from $\$ 642$ million in 1960 to over $\$ 14$ billion in 1980 , a 21 -fold increase and a $7-8 \%$ slice of all public school expenditures. Not content to play the silent banker. the federal government also directed how schools should spend the federal contribution. Thus was born one of the great educational debates of the 1970s - how much control should be maintained at the federal level and how much discretion should remain in state and local agencies? Should there be narrow. carefully regulated categorical grants or broadly defined block grants:?

On one side of the issue stood many state and local district practitioners who argued that federal regulations are an unwarranted intrusion into local decision-making. To them. the regulations were needlessly stringent, required inordinate amounts of paperwork. and ignored diverse needs and strengths of state and local districts. Federal money. they argued. should arrive with as few strings as possible.
The states and localities should decide how to allocate the money.

On the other side stood a broad arraly of persons who argued that the federal government should use its limited resources to achieve national goals. Representatives of special interest groups pointed out - with much justification - that the federal government respects the needs of the educationally and economically disadvantaged as many of the states do not. If states were free to spend federal money as they wish, these and other federal priorities would suffer. Additionally, many members of Congress believed that the federal government must maintain control over how and in what ways recipients will spend federal funds.

The 1982-1983 school year saw the resolution of this debate, at least in part, in President Reagan's successful efforts to consolidate 28 separate categorical aid programs into a single block grant Chapter 2 of the Education Consolidation and Improvement Act of 1981. What has been the impact of that legislation? Were the supporters arguments realized? Are the schools and school children better or worse off? Has it made a great difference?

This article. drawn from two more detailed $198+1$

This article offers a summary of two detated reports prepared for the National Institute of Education (Kearney. 1983. 
reports (Kearney 1983, 1984), attempts to answer some of these questions by offering an assessment of the impact of the Chapter 2 block grant on Michigan education - on the state education agency, but also and principally on school districts through a close examination of the experiences of nine intermediate and local districts with Chapter 2 during 1982-1983 and 1983-1984, the first and second years of the program.

\section{INTERGOVERNMENTAL RELATIONSHIPS}

There is no question that Chapter 2 in Michigan has led to a reshuffling of local-state-federal relationships. The reshuffling has taken one of three forms. First, there has been a demise if not total elimination of the relatively strong sets of relationships that grew out of the prior categoricals. The strong ties between the local districts and the federal level established under the Emergency School Aid Act (ESAA) grants are gone. Also gone are the ties between the local districts and the state agency that evolved from the Title IV.C program, as well as the state-federal tie that was an inherent part of that program.

Second. Chapter 2 generally has not resulted in huilding new relationships among the local, state and federal levels. If anything. Chapter 2 is marked by an absence of intergovernmental relationships. except for the bare minimums required to administer the program. This is particularly true in terms of local and state relationships with the federal level. As far as Chapter 2 is concerned, it appears that the Administration has been quite successful in achieving one of the goals identified in the education plank of the 1980 Republican Party Platform. namely. ... deregulation by the Federal Government of public education."

Third, there is some evidence that Chapter 2 in Michigan has resulted in changed local-local relationships or, more properly, local district-intermediate district relationships. Intermediate school district staff see (hapter 2 as providing additional leverage to convince local school district practitioners of the viability and usefulness of intermediate district programs and services.

This reshuffling of relationships among the local. state and federal levels has led, in turn. to the advent of two closely related issues: the lack of overall programmatic direction coming from the U.S. Department of Education as a result of its
. stance on 'non-regulatory guidance" and the lack of specific guidance and direction regarding evaluation activities. Both of these issues are of substantial concern to state education agency officials. However, neither issue is of particular concern to practitioners at the local district level. With one exception. local districts generally welcome the lack of federal and state guidance and intervention The exception comes from evaluation personnel in some of the larger districts who express serious concerns about the lack of direction in evaluation coming from both the federal and state levels.

\section{STATE LEVEL DECISIONS AND ACTIONS}

Year 1 (1982-1983) was marked by an initial period of high activity for the State Chapter? Advisory Committee as it dealt with and made recommendations on major policy issues. The Committee had addressed four major issues. The first was the question of whether intermediate school districts would be eligible for Chapter ? funds. The Committee recommended that they should be and the State Board of Education adopted the Committee's recommendation. The second issue dealt with the $8(0 / 20$ split'. that is, whether the state agency should retain a full $20 \%$ of the Chapter 2 monies and pass through' only the remaining $80 \%$ to the locals. After the State Superintendent committed himself to allocating $\$ 400.000$ of the $20 \%$ monies to establish a discretionary grant program. the Committee recommended, and the State Board adopted, the $8(1 / 20$ split. The third issue dealt with the question of whether the intermediate or local district would be the agency to administer the Chapter 2 program for the non-public schools. After some debate. the Committee's recommendation. again adopted by the State Board. Was that the administering agency could be either the local district or the intermediate: the decision was to be left to the parties at the local level. The final issue. on which the Committee spent the majority of its time. centered on the development of the formula to be used in allocating the $80 \%$ monies to the locil school districts. A four-factor formula was recommended by the Committee and adopted by the State Board. In addition to a membership factor. three high cost factors were incorporated into the formula - low achiesement desegregation and sparsity

For year 2 . an far at the State was concerned it was business as usual. No changes were made in the 


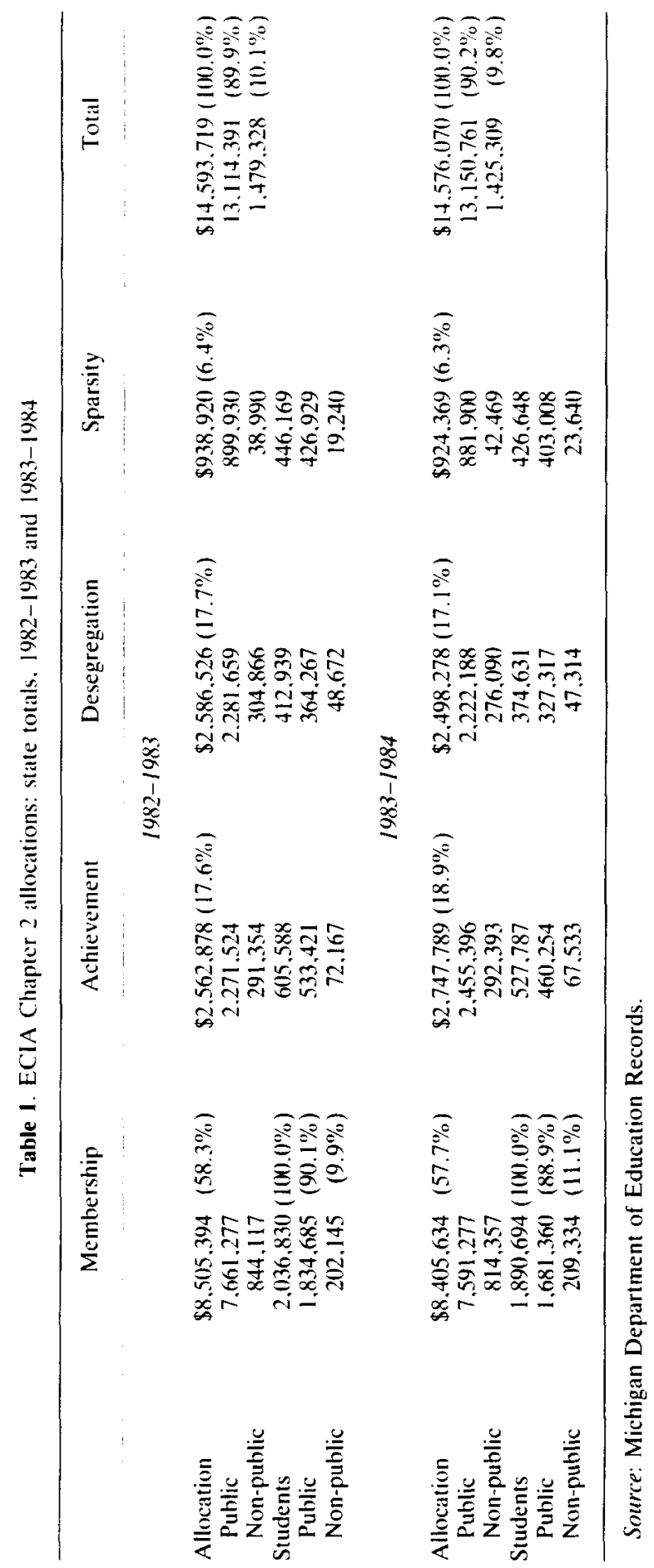


formula and consequently the distribution of Chapter 2 funds changed little from year 1 to year 2. A comparison of the distributive effects of the Michigan formula in years 1 and 2 is presented in Table 1 . The $80 / 20$ split also held firm. The question of which agency, local or intermediate, would administer the program for the non-publics continued to be left to local choice. The intermediates continued to receive the same share of the allocation $-2.5 \%$ for all 57 intermediates, another $10 \%$ for those 22 intermediates which served also as regional educational media centers.

\section{GENERAL IMPRESSIONS}

Local school district practitioners in Michigan generally view the Chapter 2 block grant as a good thing, as a program that is worthwhile, as a program that gives them freedom and flexibility to do some things that otherwise might not get done as quickly or as thoroughly. The single 'fly in the ointment', at least for the urban districts, is the loss of the ESAA funds. If the ESAA funds had not been included in the block grant, then local school district practitioners in Michigan, perhaps without exception. would rate Chapter 2 as a much-needed and longawaited improvement in the packaging of federal funds for education.

A second general impression that comes from our examination of the impact of Chapter 2 in Michigan is the unmitigated success of the federal government in deregulating the categorical programs that became a part of the block grant and, perhaps more importantly, in keeping to an absolute minimum federal regulation of and intervention in the new block grant. The U.S. Department of Education's stance on 'non-regulatory guidance' has led to an almost complete absence at the state and local levels of any federal presence in the areas covered in the block grant. Generally this is viewed as a positive development by practitioners at the local level. At the state level it is met with mixed reviews. particularly by those officials charged with responsibilities for evaluation of the Chapter 2 program.

Chapter 2 also appears to be fast becoming an institutionalized program at both state and local levels, with its newness quickly wearing off, its idiosyncrasies fast being resolved and its availability as a relatively unrestricted source of funds - albeit a small source for most school districts. but a larger source for the state - becoming an accepted fact. Most districts are now comfortable with Chapter 2 . The amounts received have remained approximately the same from year 1 to year ? (see Table 1 ). In both years 1 and 2 approximately $60^{\circ} \%$ of the funds were allocated under the membership factor: the highcost factors of low achievement and desegregation accounted for $34 \%$ of the distribution $-17 \%$, each: sparsity accounted for the remaining $6^{\circ} \%$. The nonpublic sector's share was $9-10 \%$ in both years - a five-fold increase from pre-Chapter 2 dalys. Year 3 will be no different.

The state agency also is generally comfortable with Chapter 2: it also is considerably dependent upon the $20 \%$ funds that accrue to it from Chapter 2. It drew on Chapter 2 to support hetter than 70 positions in the agency in 1982-1983 and better than 60) positions in 1983-1984. To lose Chapter 2 funding would be of great consequence to the state agency. while it would be of some but perhaps not serious consequence to most locil districts. As can be seen from Table 2. little has changed from vear 1 to year 2. Apart from the $\$ 400,0(00)$ allocated to the discretionary grant program. the agency continues to use the $20 \%$ funds to hold on to what it had. not

Table 2. The Michigan Department of Education 's usc of the $20 \%$, lunds

\begin{tabular}{lcr}
\hline \multicolumn{1}{c}{ Activity } & $\begin{array}{c}\text { Funded } \\
\text { positions }\end{array}$ & Amount \\
& Year $1,1982-1983$ & \\
Subpart A & 2.5 & $\$ 97.129$ \\
Subpart B & 66.5 & 2.869 .676 \\
Subpart C & .5 & 35.195 \\
State administration & +.5 & $250.0100)$ \\
Sea discretionary grants & & $+(01.0100$ \\
& & \\
Totals & 74.0 & $\$ 3.652 .0000$
\end{tabular}

Year 2. 1983-1984t
Subpart A

Subpart B

Subpart $C$

State administration Sea discretionary grant

Totals
$\$ \quad 149.274$

2.738 .535

77.1126

279.200

$+010.01101$
Source: Michigan's ECIA Chapter 2 State Plan.

None: Subpart A deals with basic skills development. subpart B with educational improvement and support services and subpart (" with special projects. 
to move out in any different way to fashion new staffing and programming priorities. The $20 \%$ funds indeed have become institutionalized.

From the point of view of state policy-makers and, to a much more limited extent. some local practitioners, the Chapter 2 program in Michigan is still small potatoes". Neither the Governor nor the Legislature have taken an interest in the program. The $\$ 18$ million, while a substantial amount of money in absolute terms, still represents a relatively small amount of money when compared to the total state budget or even to the education portion of the budget. During 1983-1984 the Governor and the Legislature have been preoccupied with restoring fiscal soundness to the state budget. The $\$ 18$ million in Chapter 2 monies does not make an appreciable dent in a $\$ 10$ billion budget. As an Advisory Commission on Intergovernmental Relations (ACIR) study suggests, a block grant is not going to be of consequence unless the amount of federal dollars are ".. substantial relative to the subnational expenditures, total federal outlays in the same area. and to categorical programs excluded from the particular block grant" (ACIR, 1977). Chapter 2 has yet to meet these criteria in Michigan or. for that matter. in any other state.

\section{SPECIFIC IMPRESSIONS}

As we note above. local districts are much more comfortable with Chapter 2 in year 2. They seem to be looking on it less as a short-term windfall and more as a continuing. somewhat stable funding source - albeit a relatively minor one for most districts. It represents a no strings attached' sum of money that permits them to do some things that perhaps they would not have done otherwise or. more probably, would not have done as quickly or at the same level. This became a hit more evident in year 2. It appears that there has been a minor shift in expenditure patterns among some of the districts we visited. While year 1 saw these districts allocate substantial parts of their Chapter 2 allocations to expenditures previously covered under Title IV-B. year 2 is seeing a gradual shifting away from durable goods" types of expenditures. Chapter ? monies are going more toward staff. staff development. curricular improvements and the like. It is not that the instructional equipment and materials expenditures have dropped. but rather that the districts are picking up the slack calused by the loss of Title IV-B monies by using their own general funds. The purposes of Title IV-B seem to have been incorporated into local district budgetary plans with little evidence of fiscal strain - at least apparent fiscal strain. However, a notable exception to this pattern was seen among the non-public schools we visited. As one local administrator put it. "They are still doing the old Title IV-B things." By and large, the non-publics continue to request equipment and materials.

Another impression that ont gets from visiting with local public school practitioners is that a good deal of careful thought and planning has gone into the use of Chapter 2 funds. With one exception. we did not encounter a district among the nine which we visited that had rushed out to buy microcomputers. If they bought them with Chapter 2 funds, and some of them did, the purchases were part of an overall strategy or plan that was fairly carefully laid out. Micro-computers are pervasive. but as components in well-developed and wellimplemented strategies which, for the most part are funded from the district's own general funds. One might argue, as some of our respondents suggested. that one reason Chapter 2 'works' is that there is in most local districts a 'bank' of talent. expertise. know-how and the like that has been built up as a result of experiences with the massive array of federal and state categorical programs that sprang up during the 20 years following the 1965 passage of the Elementary and Secondary Education Act (ESEA). This, of course, is largely conjecture, but nevertheless interesting conjecture. What would have been our experience if the block grant rather than the categorical approach had been selected as the instrument to achieve the federal government 's 1965 education policy goals? Did the categorical approach of the past 20 years produce a cadre of practitioners skilled in planning. project management and evaluation? Are we now reaping the benefits?

Activities funded under Chapter 2 in year 2 are not narrowly focused. Block grant funds are being used to support a broad array of activities: Ann Arbor's hiring of a facilitator to help implement its teacher in-service program: Ludington's assignment part-time of a mathematics teacher to provide inservice training to its teachers in the use of the microcomputer as a classroom instructional tool: Benton Harbor's hiring of three minimal skills teachers to work with primary grade students having difficulties 
in reading and math: Grass Lake's purchase of micro-computer hardware and software: Detroit's support of its district-wide guidance and counseling program; East China's establishment of a gifted and talented program for elementary school pupils: Carman-Ainsworth's purchase of relatively expensive items to enhance its physical and biological sciences curriculum: Genesee Intermediate's portfolio of services to local school districts: Powers Catholic High School's program in the humanities: and Flint's 'rear-guard' action to save its magnet elementary schools. These represent some of the activities being supported in the nine districts: in each district, except Detroit, there also are other activities being supported with Chapter 2 dollars.

The discretionary grant program established through the use of $\$ 400.000$ of the state agency's $20 \%$ funds is viewed as offsetting, to some extent, the loss of opportunities for creativity and innovation resulting from the termination of Title IVC. While the $\$ 400,000$ is significantly less than the state's previous annual allocations under Title IV-C. there is some feeling that the potential for in novation inherent in Title IV-C has not all been lost.

There are problems. Detroit, Flint and Benton Harbor are still big losers in absolute dollars because of the demise of ESAA. Detroit continues to experience 'double jeopardy'. It loses dollars because of the demise of ESAA. but does not lose the obligation to conduct the activities the dollars supported. Detroit simply has no choice but to continue to assign its full Chapter 2 allocation to help fund the guidance and counseling component of its court-ordered desegregation plan. The coordinator of Flint's magnet elementary school program. which is mandated under a consent decree. states frankly that the program. for all practical purposes, will cease to exist in a year or two because of the loss of ESAA funds. The director of federal programs in Benton Harbor would be a staunch supporter - rather than just a supporter - of the Chapter 2 block grant if only it had excluded ESAA.

There remains a concern among public school people in Michigan over the appropriateness, if not the constitutionality, of non-public school participation in Chapter 2. However, they see the resolution of this question lying not at the local or state level but rather the federal level. The actual operation of the program is largely without incident. With the exception of the problem of carrying funds over to a new fiscal year to help support summer staff and curriculum development activities. the non-public schools experienced few problems with Chapter 2. Participation in the block grant program appears to be going smoothly. Three of the local districts in our sample work directly with the nonpublic schools and would have it no other way. They contend they are building on long-standing. important and positive relationships. Five of the districts leave the administration of non-public participation to the intermediate districts. They see no benefits - and no costs in terms of maintaining positive relationships - in administering the program directly. While a sizeable percentage of the non-public school children in Michigan participate in Chapter 2 activities. there is a number that do not. By and large. these children attend schools of a fundamentalist religious persuasion: the adherents are basically opposed to any governmental intervention in their schools and decline to participate in funded programs.

The non-public schools in Michigan continue to be winners under Chapter 2. Their share of Chapter 2 resources continues to represent a five-fold increase over the resources available to them under the prior categoricals. This results, in part, from the non-public school becoming eligible for the same weighted allocation per pupil as the public school district in which it is located. even though the nonpublic school is not necessarily impacted by the same high cost factors.

As we noted earlier, the non-publics tend to use their allocation to request 'durable goods" - instructional equipment and materials covered previously under Title IV-B. rather than to undertake staff development. curriculum building and like activities. If there is a need that became evident. it is the need for training of staff in the non-public sector in the appropriate instructional uses of these durable goods", particularly computer hardware and software. It is not that they do not have the hardware. It is that they do not know how to use it.

Educational reform is abroad in the land - and particularly in Michigan. The Michigan Commission on High Schools, the State Republican Caucus, the Speaker of the House and the State Board of Education have all issued calls for reform and three have backed up the calls with sweeping sets of recommendations. Local districts are responding to these calls, as well as to the national calls. Indeed. many of them had improvement efforts well underway prior to the issuance of the national and state 
reports and studies. With one exception. however. there has been little if any relationship between local reform efforts and Chapter 2 expenditures. The lone exception was at the intermediate level where Chapter 2 funds were used to support a series of activities designed to help local districts respond to A Nation At Risk. The national and state reports did not drive nor influence local decisions regarding Chapter 2 expenditures. Chapter 2 does not represent a mechanism to fund reform efforts in Michigan.

Generally, local district practitioners welcome the lack of any federal presence. as well as the minimal state presence. associated with Chapter 2. They also welcome the substantial reduction in paperwork and red tape associated with the program. They generally prefer to be left on their own to decide how and on what their Chapter 2 funds will be spent. With the exception of local evaluators in some of the larger districts. they are not eager to seek either direction or technical assistance from the state. However, state agency officials are nowhere near as sanguine about the U.S. Department of Education's stance on 'non-regulatory guidance'. They express a certain frustration in not being able to get clear. decisive answers to the programmatic and fiscal questions they raise with federal agency staff. This was particularly apparent in the area of evaluation. where the federal stance was viewed as a lack of needed national leadership. Program evaluators, at the local as well as the state level, argue that this lack of direction will lead to a situation where little if any good evidence will be available to support the continuation of the program and. consequently, to an eventual termination by the Congress of Chapter 2 funding. One might argue that program evaluators may be more motivated by concerns for self survival than for program survival. Program cvaluation, to a considerable extent, is a product of the Great Society programs of President Lyndon Johnson and the call of Senator Robert Kennedy for hard evidence to judge the efficacy of those programs. One result of the movement from a categorical to a biock grant approach may be the demise of program evaluation. at least as we currently view that function. Evaluators, generally being astute persons. probably have contemplated the possibilities of such an outcome.

Yet. even though the evaluators and, to a lesser extent, the program administrators decry the almost total absence of federal guidance and direction. the state agency appears to administer the program quite effectively and efficiently. Information on annual allocations, application procedures, deadlines, evaluation requirements and other aspects of the program goes out in prompt and timely fashion to Incal districts. Any problems apparently are quickly cleared up by telephone. The locals generally view the state agency's administration of the program in a very positive light. In short, the program runs smoothly from both the local districts' and the state agency's viewpoints.

A final impression, perhaps a general impression rather than a specific impression, is that at both the local and state levels judgements about the efficacy of Chapter 2 center more on the question of means rather than the question of ends. For the local practitioner, as well as for many of the state agency staff, there is a preoccupation with questions about the packaging of federal aid rather than questions about the purposes and goals of federal aid - a sort of removal from the ultimate policy questions of what the federal role should be and why. In effect. the concern is more with the means. i.e. the mechanisms being used to achieve a goal, than with the goal itself, i.e. the question of whether there is a legitimate national interest, a legitimate national purpose heing served by the prior categorical Perhaps one should not be surprised at this. Perhaps questions about national goals are best addressed. and only can be addressed effectively, at the national level by the Congress.

Arknowledgements - The rescarch reported herein was supported by a grant from the National Institute of Education (contract No. NIE 40(0-81-0(04) to E.H. White and $\mathrm{Co}$. Contractors undertaking such projects under government sponsorship are encouraged to express freely their professional judgement in the conduct of the project Points of view or opinions stated do not. therefore. necessarily represent official National Institute of Education or E.H. White and Co. position or policy. The author wishes to thank the many professional staff members of the Michigan Department of Education particularly Daniel Schultz, Philip Hawkins. Patricia Slocum. and Paul Novak - for their generous cooperation in the conduct of this study. Thanks are also due to the numerous intermediate district. local district and nonpublic school officials in Michigan who gave generously of their time and who contributed most of the information of which this article is based. 


\section{NOTES}

1. "The education plank, the 1980 Republican Party Plattorm." as reported in Edacamon Times. September. 1980 .

\section{REFERENCES}

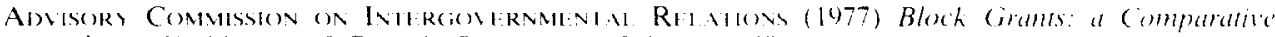
Analysis. Washington. DC: U.S. Government Printing Oflice.

KEskni:r. C.P. (1983) The education block grant in Michigan: initial experiences with (hapter 2 of the Education Consolidation and Improvement Act. An unpublished ease sudy undertaken for the National Institute of Education, U.S. Department of Edtcattion,

KIARNt:Y. C.P. (1984) Michigan's second vear experiences with the education block grant. An unpublished ease study undertaken for the National Institute of Education. L.S. Department of Education. 